\title{
Norbert Elias
}

\section{Et blik på en ridders liv}

At spørge om hvorfor menneskers adfærd og affektleje ændrer sig, er i grunden det samme som at spørge om hvorfor menneskers livsformer ændrer sig. Der var i middelaldersamfundet bestemte livsformer, der var mønstergyldige, og den enkelte var, hvad enten han nu var ridder, håndværker eller livegen, tvunget til at leve under disse former; i det senere samfund forefandt den enkelte andre muligheder og andre livsformer, som han måtte tilpasse sig; han kunne, hvis han var adelig, leve en hofmands tilværelse; men han kunne ikke mere leve en ridders utvungne liv, selv om han måtte ønske det - og mange ønskede det. Fra et bestemt tidspunkt var denne funktion og livsform ikke længere tilstede i samfundsstrukturen. Andre funktioner der, som f.eks. præstens eller håndværkerens, spillede en overordentlig stor rolle i den middelalderlige fase, tabte i større eller mindre grad betydning i forhold til de samfundsmæssige relationers totale struktur. Hvorfor forandres i historiens løb de funktioner og livsformer, der indkapsler den enkelte som mere eller mindre fast modellerede hylstre? Det er, som før sagt, i grunden det samme som at spørge efter årsagerne til, at driftslivet, affektmodelleringen og alt hvad der hænger sammen dermed forandrer sig.

Der er i det foregående blevet sagt mangt og meget om den midelalderlige overklasses affektstandard. For fuldstændighedens skyld, og samtidig også som overgang til spørgsmålet om forandringsårsagerne, skal vi blot tilføje et kort indtryk af den måde, som ridderne levede på, dvs. et indtryk af det livsrum som dette samfund åbnede op for den adeligt fødte, og sidenhen lukkede ham inde i.Allerede kort tid efter, hvad man dengang kaldte rid- 
dernes »undergang «, indhyllede billedet af dette livsrum, samt billedet af ridderen overhovedet, sig mere eller mindre i tåge. Hvad enten man kun så den "ædle ridder « i den middelalderlige kriger og kun bevarede det storladne, smukke, eventyrlige og patetiske ved denne tilværelse $\mathrm{i}$ erindringen, eller kun så »feudalherren« $\mathrm{i}$ den middelalderlige kriger, bondeskænderen, og blot fæstnede sig ved det vilde, grusomme og barbariske ved hans tilværelse, så blev det enkle billede af dette sociale lags livsrum mestendels fordrejet under vægten af værdidomme og længsler, udsprunget af betragterens egen tidsalder. Et par tegninger, eller rettere en beskrivelse af dem, kan her hjælpe til at genfremkalde dette billede. Bortset fra enkelte skrifter er det især billedhuggeres og maleres efterladenskaber fra denne tid, der særligt stærkt lader en fornemme atmosfærens, eller om man vil, affektmodelleringens egenart og dermed forskellen til vor egen, omend det kun er få billedværker, der virkelig afspejler ridderens liv i sammenhæng. En af de få billedbøger af denne slags (der ganske vist er forholdsvis sen, fra tiden mellem 1475 og 1480) er den serie af tegninger, der blev kendt under den ikke helt fyldestgørende titel »Den middelalderlige husbog «. Navnet på den mester, der skabte den, er ubekendt, men det må have været en mand, der var meget fortrolig med sin tids ridderliv og som til forskel fra mange af sine håndværkerfæller så på verden med ridderens øjne og i vid udstrækning identificerede sig med hans sociale vurderinger. Et ikke helt ubetydeligt fingerpeg $\mathrm{i}$ den retning er at han på et af bladene, af alle håndværkerne kun fremstiller den mand, der repræsenterer hans eget erhverv, i hofdragt; det samme gælder pigen, der står bag manden og lægger sin hånd på hans skulder, og for hvem han tydeligt bringer sine følelser til udtryk. Måske er det et selvportræt.

Som sagt stammer tegningerne fra ridderskabets sene tid, fra de sidste riddere, Karl den Dristiges og Maximillians tid. At dømme efter våbenskjoldene er endog begge disse, eller riddere der står dem nær, selv fremstillet på dette eller hint af billederne. "Der består slet ingen tvivl om, at vi for os har Karl den Dristige selv eller en burgundisk ridder fra hans omegn «, er det blevet hævdet. Nogle turneringsbilleder er måske den direkte fremstilling af kamplege efter Neusser-fejden (1475) i anledning af Maximillians 
forlovelse med Karl den Dristiges datter, Marie af Burgund. I hvert fald er de menesker, man ser for sig, allerede fra den overganstid, hvor et hofaristokrati langsomt trådte i stedet for ridderaristokratiet. $\mathrm{Og}$ der findes mange ting i disse billeder, der leder tanken hen på hofmandens væremåde. I det store og hele giver de dog alligevel et ganske godt begreb om det specifikt ridderlige livsrum, om det ridderen fyldte sin dag ud med, om de ting han så omkring sig. Og samtidig også et begreb om hvordan han så dem. Hvad ser man da?

Næsten altid det åbne land, og næsten ikke noget der virker byagtigt. Små landsbyer, marker, træer, enge, bakker, små vandløb og ofte borgen. Men man sporer i disse billeder endnu intet af den længselsstemning og »sentimentale« holdning til »naturen«, som bliver mærkbar ikke så lang tid efter, når den overvejende del af adelen i stadig stigende grad må afgive afkald på det utvungne liv på de landlige stambesiddelser for at blive bundet i større afhængighed af kongen eller fyrsten ved det halvt bylignende hof. Det er en af de største forskelle i affektleje, som disse billeder her lader ane. Senere antager den bevidsthed overfor det sete, som kommer til udtryk i den kunstneriske fremstilling, karakter af en overordentlig streng og meget specifik slektion, der direkte udtrykker tegnerens smag, eller rettere sagt, affektmodellering. "Naturen«, det åbne land, der førhen næsten altid fremvistes som baggrundstæppe for mennesker, antager en længselsaura i fremstillingen, efterhånden som den by- og hofmæs-sige udvikling også inddrager overklassen og gør adskillelsen mellem by- og landliv mere mærkbar; eller også antager den en ophøjet, repræsentativ karakter i billedet, som de mennesker den omgiver. I hvert fald forandres den affektive selektion i forhold til naturfremstillingen og det i den, der opfattes som henholdsvis tiltalende eller ubehageligt og pinligt; noget lignende gælder de afbildende mennesker. Meget af det der virkelig findes på landet, altså i »naturen«, vises ikke længere for det absolutistiske hofpublikum. Man viser en bakke, men ikke den galge med hængte i, som står på den. Man viser marken, men ikke den pjaltede bonde, der møjsommeligt driver sine heste fremad. Ganske som alt »gement《 eller »vulgært« forsvinder ud af hoffets sprogbrug, forsvinder det også fra de billeder og tegninger, der er bestemt for overklassen. 
Det forholder sig anderledes i tegningerne fra »husbogen «, som giver en forestilling om den senmiddelalderlige overklasses følelsesleje. Her finder vi det hele. Galger, lasede trælle, møjsommeligt arbejdende bønder; som i livet, således også i tegningerne, og det forekommer vel at mærke ikke betonet og fremhævet, som tilfældet ville være i langt senere tiders protestøjemed, men optræder som noget ganske selvfølgeligt, noget man ser omkring sig til daglig, ganske som en storkerede eller et kirketårn. Det ene er lige så lidt pinligt som det andet i tilværelsen, og det forekommer derfor heller ikke pinligt i fremstillingen. Tværtimod hører det overalt i middelalderen til de riges og ædles tilværelse, at der findes tiggere og krøblinge, der rækker hånden frem; bønder og håndværkere, der arbejder for én; deri ligger der ingen trussel; man identificerer sig på ingen måde med dem; synet af dem vækker ingen pinlige følelser. Til og med gør man sig ofte lystig over den evindelige klodsmajor, bonden.

Således er også disse billeder. Først kommer en serie tegninger, der viser mennesker under et bestemt stjernebillede. De er ikke direkte grupperet omkring ridderen, men anskueliggør dog hvad han ser omkring sig, og på hvilken måde. Så kommer en række af blade, der direkte viser, hvad ridderen tilbringer sin tid med, viser hans beskæftigelser og hans glæder. Målt med eftertiden vidner de alle om den samme pinlighedsstandard og den samme, sociale holdning.

F.eks. ser man lige i begyndelsen folk, der er født under Saturn. I forgrunden er en fattig stakkel ved at tage indvoldene ud af en segnet hest, eller måske prøver han at skære det brugbare kød af. Idet han har bukket sig, er hans bukser gledet lidt ned, bagdelen titter frem og en so står bagved ham og snuser til den. En gammel, gebrækkelig kone, halvt klædt i pjalter, går haltende forbi, idet hun støtter sig til en krykke. I en lille hule ved vejen sidder en ynkelig mand med hænder og fødder i gabestok, og ved siden af ham har en kone den ene hånd i gabestok og den anden lagt i lænker. En bondekarl graver ved et vandløb, der fortaber sig mellem træer og bakker. I det fjerne ser man bonden og hans lille dreng, der møjsommeligt pløjer den bakkede mark med en hest. Længere væk bliver en laset mand ført til galgen, ved siden af ham står bøddelen stolt med en fjer $\mathrm{i}$ hatten; på den anden side har vi en 
munk i kutte der holder et stort kors hen for ham; bagved rider ridderen og to af hans mænd. Oppe på bakken står galgen med en hængt, samt hjulet med et lig på. De sorte fugle flyver omkring; en af dem hakker $i$ kadaveret.

Galgen er på ingen måde fremhævet. Den er der bare som bækken eller som et træ, og det er nøjagtigt sådan man ser den, når ridderen går på jagt. Her rider et helt selskab forbi, man ser $\mathrm{i}$ flere tilfælde herre og dame på samme hest. Vildtet forsvinder i en skov, en hjort synes at være ramt. Længere borte ser man en lille landsby eller måske er det hovedgården; man ser en brønd, et møllehjul, en vindmølle, et par bygninger; ser bonden pløje på marken; han kigger efter vildtet, der netop løber tværs over hans jord. I den ene side ser man højt oppe borgen, overfor ser man mindre høje med hjul og stejle, og fugle der flyver rundt.

Galgen, symbolet på ridderens domsmyndighed, hører til kulisserne omkring hans liv. Den fremtræder måske ikke som særlig vigtig, men synes i hvert fald heller ikke særlig pinlig. Domfældelse, henrettelse, død, alt dette er meget mere nærværende i denne tilværelse og er endnu ikke lagt om bag kulisserne.

Det samme gælder gælder de fattige og de arbejdende. »Hvem skulle dyrke vore marker, hvis I alle var herrer«, siger Berthold v. Regensburg i en af sine prædikener fra det 13. årh. Og ved samme lejlighed siger han endnu tydeligere: „Jeg vil fortælle jer kristenfolk om hvorledes den almægtige Gud har ordnet den hellige kristenhed i ti slags mennesker,og hvilke tjenester de nederste er de øverste skyldige og underdanige. De første tre er de højeste og de herskende, som den almægtige Gud selv har valgt og for hvem han har tilforordnet, at de andre syv alle skal være dem underdanige og tjene dem.« Den samme livsstemning kan man endnu spore $\mathrm{i}$ disse billeder fra det 15 . årh. Det er ikke pinagtigt, men derimod et udtryk for tilværelsens naturlige og selvfølgelige orden, at krigerne, de ædle, har frihed til at fornøje sig, og at de andre arbejder for dem. Menneskers indbyrdes identificering er fraværende. Ikke engang ude i horisonten af denne livsform findes der en forestilling om, at alle mennesker skulle være »lige«. Men det er måske netop derfor, synet af de arbejdende ikke har noget beskæmmende eller pinligt over sig.

Man ser storgården og herrernes glæder: En adelig jomfru be- 
kranser sin unge ven. Han trækker hende indtil sig. Et andet par spadserer, tæt omslyngede. Den gamle tjenestepige gør en grimasse over de unge menneskers elskovsleg. Ved siden af arbejder trællene. Èn fejer $\mathrm{i}$ gården, en anden strigler hesten, en tredje strør foder til ænderne, da en pige vinker til ham fra vinduet, han vender sig og forsvinder snart ind i huset. I forgrunden legende adelsjomfruer, i baggrunden bondsk beskæftigelse. På taget knebrer storken.

Dernæst ser vi en lille forgård ved søen. På broen står den unge adelsmand med sin viv. De læner sig til gelænderet og ser, hvordan trællene fanger fisk og ænder i vandet. Tre unge damer sejler i en båd. Siv, små buske og i det fjerne en lille bys mure.

Eller vi ser arbejdere, der bygger et hus foran et skovbevokset bjerg. Borgherren og borgfruen ser til. Man har slået pæle ind i det lille bjerg for at udvinde sten. Man ser arbejderne hugge i stenmassen, andre triller stenene væk. I forgrunden er der folk, der arbejder på det halvfærdige byggeri. Helt foran skændes nogle arbejdere; de er lige ved at slå og stikke hinanden ned. Borgherren står ikke langt fra dem. Han viser sin frue de stridendes skuespil; herrens og fruens fuldkomne ro er sat i stærk kontrast til de stridendes ophidsede fagter. Pøblen slås. Herren har ikke noget med det at gøre. Han lever i en anden sfære.

Det er, snarere end hændelserne i sig selv, som til dels ikke går anderledes for sig nu om dage, fremstillingens faktiske karakter, der understreger forskellen i følelsesleje. Den efterfølgende tids overklasse lod ikke sådanne motiver afbilde. De tiltalte ikke dens følsomhed. De var ikke "smukke" og hørte ikke hjemme i "kunsten«. En tilsvarende pinlighedsstandard findes sidenhen hos hollænderne, der repræsenterer middelstanden og andre lag der ikke knytter sig til hoffet; Brueghel tillader sig f.eks. at anbringe krøblinge, bønder, galger, eller folk der forretter deres nødtørft, på sine billeder. Men denne standard forbindes her med helt andre sociale følelser end den senmiddelalderlige overklasses.

For sidstnævnte er det selvfølgeligt, at de andre, de arbejdende lag, er der. De tilhører endda ridderlivet som en uundværlig kulisse. Herren lever midt iblandt dem. Det chokerer ham ikke at se trællen arbejde ved siden af sig eller muntre sig på sin egen måde. Det er tværtimod en iboende del af hans selvfølelse, at de andre 
mennesker bevæger sig rundt om ham og at han ikke er som dem, at han er deres herre. Denne følelse kommer til stadighed til udtryk i tegningerne. Der findes næppe en iblandt dem, hvori de høviske beskæftigelser og gestus ikke er sat i kontrast til underklassens vulgære. Hvad enten herren nu rider, jager, elsker eller danser, er han ædel og høvisk; hvad trællene og bønderne foretager sig, er grovt og plumpt. Den middelalderlige overklasses fornemmelse for pinagtighed kræver endnu ikke, at alt det vulgære bliver henlagt bag livets, og dermed også billedets, kulisser. Det giver den en følelsesmæssig tilfredsstillelse at vide sig forskellig fra de andre. Synet af kontrasten forøger livsglæden; og man bør i denne forbindelse erindre sig, at noget af denne glæde ved kontraster også kan spores hos f.eks. Shakespeare, i en noget mildere form ganske vist. Hvor man end betragter den middelalderlige overklasses efterladenskaber, finder man den samme holdning helt utilsløret. Jo mere den samfundsmæssige sammenfletning og arbejdsdeling tager til, desto mere bliver overklassen faktisk afhængig af de andre lag, og desto større bliver disse lags samfundsmæssige styrke, i det mindste potentielt. Afhængigheden af de andre lag er ganske vist ikke helt fraværende dér, hvor overklassen først og fremmest er et krigerlag og holder de andre lag nede gennem sværdet og våbenmonopolet. Men den er ubetinget ringere, og dermed bliver presset, opdriften fra neden mod oven, ringere. Overklassens herrefølelse og foragten for de andre lag er på tilsvarende vis meget mere åbenlys, og en tvang til tilbageholdelse af disse følelser er, som driftslivets binding i øvrigt, ringe.

Det er sjældent, at vi som tilbageskuende i en sådan grad får anskueliggjort denne herrebevidstheds selvfølgelige karakter og den selvsikre, patriarkalske foragt for andre, som tilfældet er med disse tegninger.Den kommer ikke kun til udtryk i den gestus, med hvilken adelsmanden viser sin frue de stridende arbejdere, eller $i$ afbildningen af de arbejdere i en slags slags støberi, der holder sig for næsen p.g.a. de ildelugtende dampe; og heller ikke kun der hvor herren betragter trællenes fiskefangst eller i den gennemgående fremstilling af galgen med den hængte, men overhovedet $\mathbf{i}$ den selvfølgelige og ufremhævede måde, hvorpå ridderens ædle gestus er sammenstillet med folkets grove.

Her har vi turneringen. Musikanter spiller op. Narrene gør 
løjer. De adelige tilskuere samtaler til hest, og man ser i mange tilfælde herre og dame på samme hest. Bonden, borgeren og lægen, der er let at kende på sin klædning, ser til. De to riddere, der virker temmelig hjælpeløse $\mathrm{i}$ deres tunge rustninger, venter inde $\mathbf{i}$ midten. Deres venner giver dem gode råd. Den ene får netop den lange stiklanse overrakt. Så blæser herolden. Ridderne stormer løs på hinanden med sænkede lanser. I baggrunden ser man så, i kontrast til herrernes høviske beskæftigelse, folkets vulgære, nemlig et hestevæddeløb der ledsages af alskens tossestreger. En mand hænger fast $i$ halen på den ene hest. Dens rytter er rasende. De andre pisker hestene, der jager frem og tilbage $i$ en grotesk galop.

Her har vi krigslejren. Der er lavet en vognborg af skytsvognene. Inde i den står de prægtige telte med deres forskellige våbenskjold og bannere, blandt dem rigsbanneret. I midten ser man kongen eller kejseren omgivet af sine riddere. En kurér til hest bringer ham netop en efterretning. Ved lejrindgangen ser man tiggende koner, der sidder med deres børn og vrider hænder, mens en pansret mand til hest netop sætter en lænket fange af. Længere borte ser man bonden, der pløjer sin mark. Udenfor lejrvolden ligger der knogler, dyreskeletter og en død hest; en krage og en vild hund spiser af den. Tæt på vognene sidder en træl på hug og forretter sin nødtørft.

Eller man ser under Mars-tegnet, hvorledes riddere overfalder en landsby. Forrest gennemborer en af krigsknægtene en bonde, der ligger ned; til højre, tilsyneladende i et kapel, bliver en anden mand stukket ihjel og hans ting liver slæbt væk. På taget sidder storkene fredeligt $\mathrm{i}$ reden. Længere borte prøver en bonde at flygte over hegnet, men en ridder til hest holder ham fast $i$ en skjortesnip, der hænger ud. En miserabel og ynkelig bonde i lænker bliver slået ned af en ridder til hest; længere borte sætter ryttere et hus i brand, én af dem driver kvæget afsted og slår løs på bondekonen, der prøver at standse ham; øverst oppe i landsbykrikens lille tårn trænger bønderne sig sammen, og ængstelige ansigter ser ud over vinduet. Helt i det fjerne står et befæstet kloster på et mindre bjerg; bag den høje mur ser man kirketaget med et kors pá. Pá et lille bjerg noget højere oppe ser man en borg eller en anden del af klosteret. Dette er hvad tegneren kunne komme i 


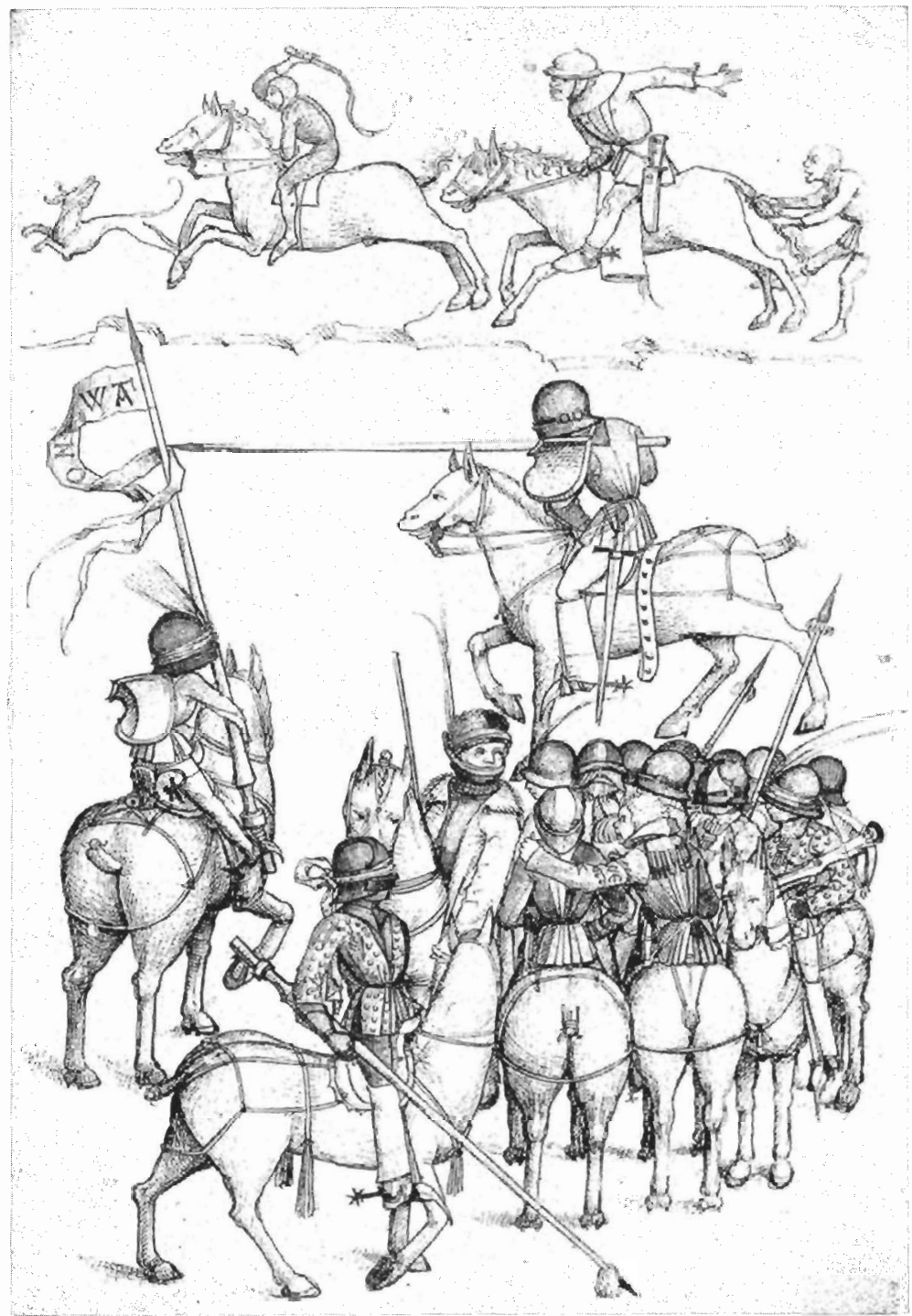

tanke om til krigsgudens stjernebillede. Bladet er vidunderligt livagtigt. Som ved en række af de andre blade har man umiddelbart fornemmelsen af at have noget virkeligt oplevet foran sig; 


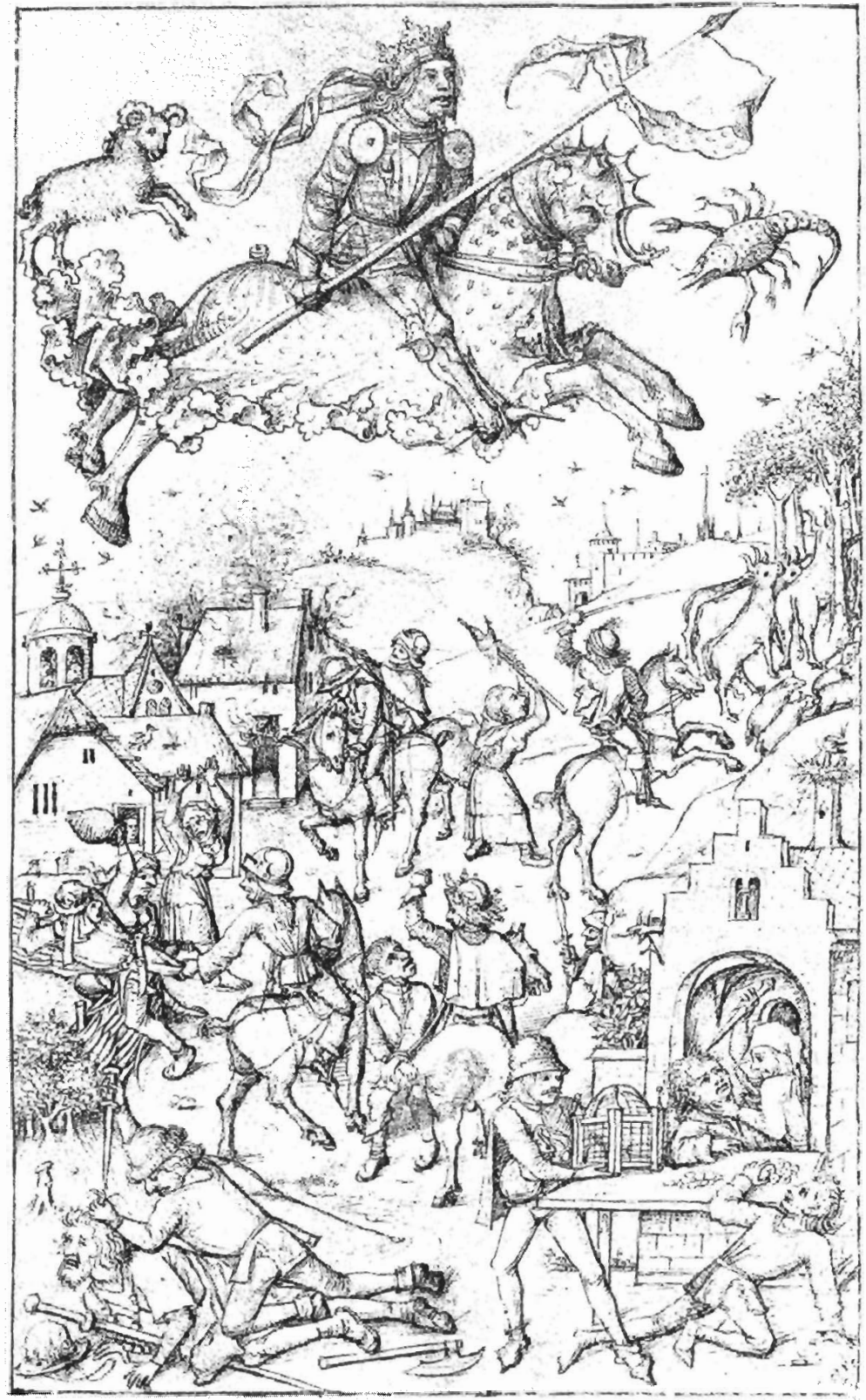


fornemmelsen skyldes at disse blade endnu ikke er "sentimentale«; det, de udtrykker, har endnu ikke karakter af den stærke affektbinding, der sidenhen over lange tidsrum kun vil forevise overklassen deres egne ønskebilleder i kunstproduktionen, og tvangsmæssigt vil undertrykke alt det der går på tværs af den fremrykkede pinlighedstærskel. Her får man simpelthen fortalt hvordan ridderen så og følte tilværelsen. Den følelseselektion og affektmodel, der kun lader det behagelige komme ind i fremstillingen og udelukker det ulystvækkende, beskæmmende og pinagtige, bevirker at mange kendsgerninger ganske uproblematisk bliver siet fra; de vil dog sidenhen trænge ind i de kunstneriske fremstillinger dér, hvor der formuleres en bevidst eller ubevidst protest mod overklassens driftscensur og vil dermed på en vis måde blive betonet og problematiseret. Men her er bonden hverken ynkværdig eller repræsentant for dyden; han er heller ikke repræsentant for afskyelige laster. Han er simpelthen en bedrøvelig og lidt latterlig skikkelse, og det er nøjagtig således ridderen ser ham. Verden er centreret omkring ridderen. Udsultede hunde, tiggende kvinder, rådnende hestekadavere, trælle der sætter sig på hug ved volden og foretter deres nødtørft, landsbyer der bliver sat i brand, bønder der bliver udplyndret og dræbt, alt dette hører i lige så høj grad som turneringer og jagt med i dette sjælelige landskab. Gud har skabt verden således, at nogle er herrer og andre er trælle. Det er der ikke noget pinligt ved.

Også i den måde, kærligheden fremstilles på, viser der sig den samme forskel mellem det senridderlige samfund og det kommende absolutistiske hofsamfund m.h.t. affektstandard. Her har vi menneskene under Venus. Igen ser man vidt ud i det åbne landskab. Der er lave bakker, buske, en lille skov og en flod, der bugter sig. I forgrunden spadserer tre eller fire par af unge adelige, ung mand og jomfru sammen; de går i ring til musik og er festklædte og elegante; de går alle i de langsnablede sko, der var på mode. Deres bevægelser er afmålte og afrundede; en af dem har en stor fjer $\mathrm{i}$ hatten, andre har kranse $\mathrm{i}$ håret. Måske er det en slags langsom dans, vi ser. Bagved står tre unge fyre og spiller, og der står et anretterbord med frugter og drikkevarer; en ung dreng, der skal varte op, læner sig op ad det.

På modstående side er der afbildet en lille have, afskærmet af 


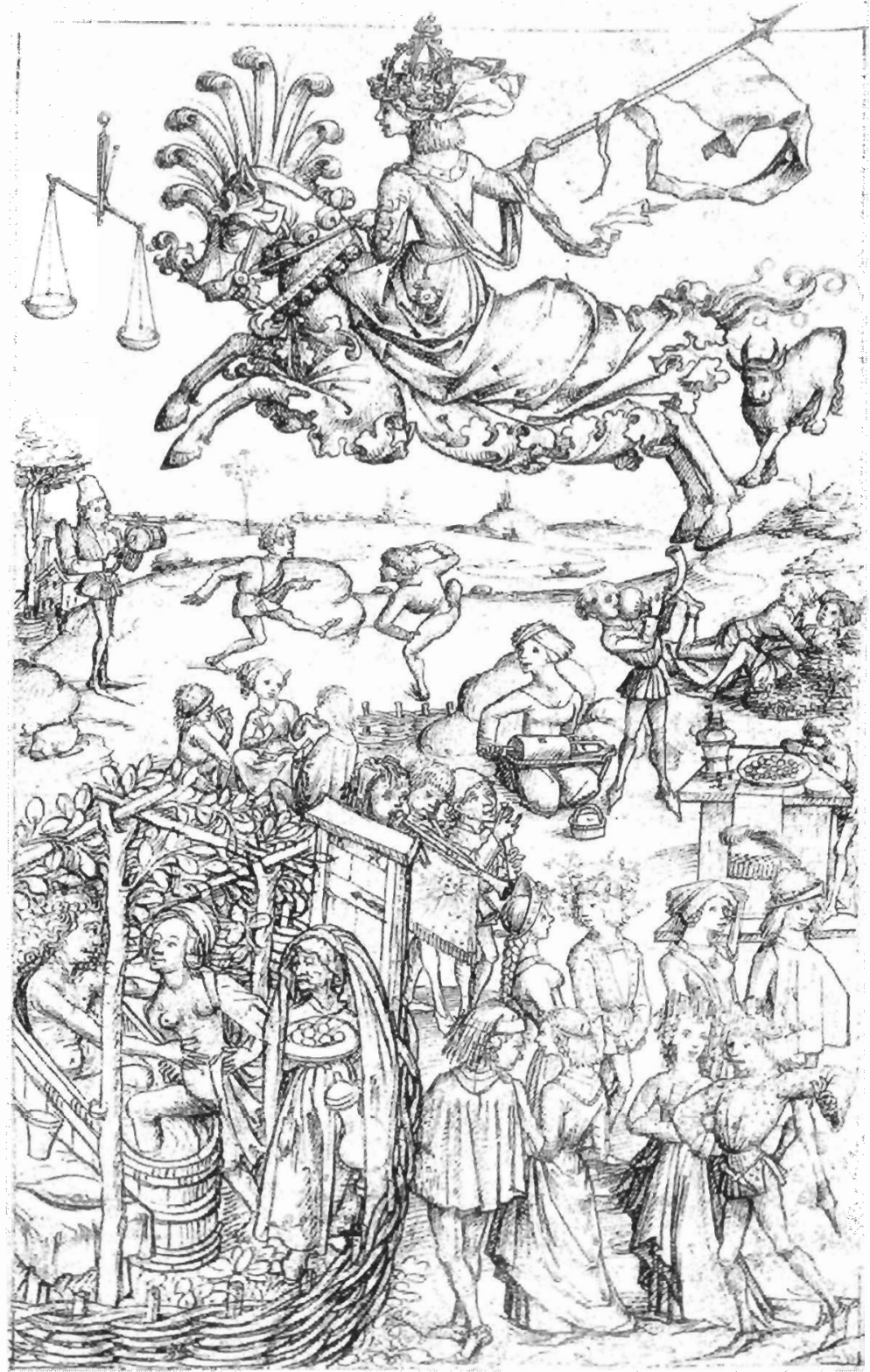


hegn og dør. Træerne danner en slags arkade, nedenunder står et ovalt badekar, der sidder en nøgen ung mand i det, han griber begærligt ud efter en nøgen ung pige, der netop er ved at træde ned $i$ baljen til ham. Ligesom ovenfor stirrer en gammel tjenestepige, der netop bringer frugter og drikkevarer, med vredt ansigtsudtryk på de unges kærlighedsleg; og som herrerne forlyster sig i forgrunden, således også trællene i baggrunden. En af dem kaster sig netop over en pige, der allerede ligger på jorden med højt optrukket skørt. Han ser sig endnu en gang omkring, om der skulle være nogen i nærheden. På den anden side danser to unge mænd, der tilhører det jævne folk, i kreds med storladne fagter, på samme måde som mauriske dansere; en tredje spiller op.

I et andet tilfælde ser man, ligeledes i det åbne landskab, et lille badehus af sten, og $\mathrm{i}$ forgrunden en lille forgård med stenmur. Man kan se om bag den. Der er antydet en vej. En række træer og noget buskads fører ud i det fjerne. I forgården er der unge par, der spadserer eller sidder ned; et af dem beundrer den nye brønd, andre taler sammen, en af de unge mænd har en falk i sin hånd. Der er hunde, en lille abe og potteplanter.

Man ser ind $\mathrm{i}$ badehuset gennem et stort åbent, buet vindue. To unge mænd og en pige sidder nøgne i vandet ved siden af hinanden og taler sammen. En anden pige, der allerede er klædt af, åbner netop døren for at stige ned i vandet til dem. I badehusets store, åbne vindue sidder en ung fyr og spiller på guitar for de badende. Under vinduet ser vi hanen, som vandet løber ud af. Foran huset er der sat kolde drikke i et lille kar med vand. På et bord ved siden af står der frugter og et bæger; en ung adelsmand sidder ved det med kranse io håret og hovedet elegant hvilende $\mathrm{i}$ hånden. Oppe fra badehusets anden sal ser karlen og pigen på, hvorledes herskabet fornøjet sig.

Som man kan se, er den erotiske forbindelse mellem mand og kvinde også fremstillet meget mere utilsløret her end i den senere fase, hvor man godt nok lader den skinne igennem, så den er forståelig for enhver, både i menneskers sociale omgang og i billederne, men hvor den dog alligevel fremtræder halvt fordækt. Nøgenheden er endnu ikke belagt med skamfølelser i en grad, så man kun kan lade den komme til udtryk som sentimentalt kostume for grækere og romere, når man skal omgå den indre og 


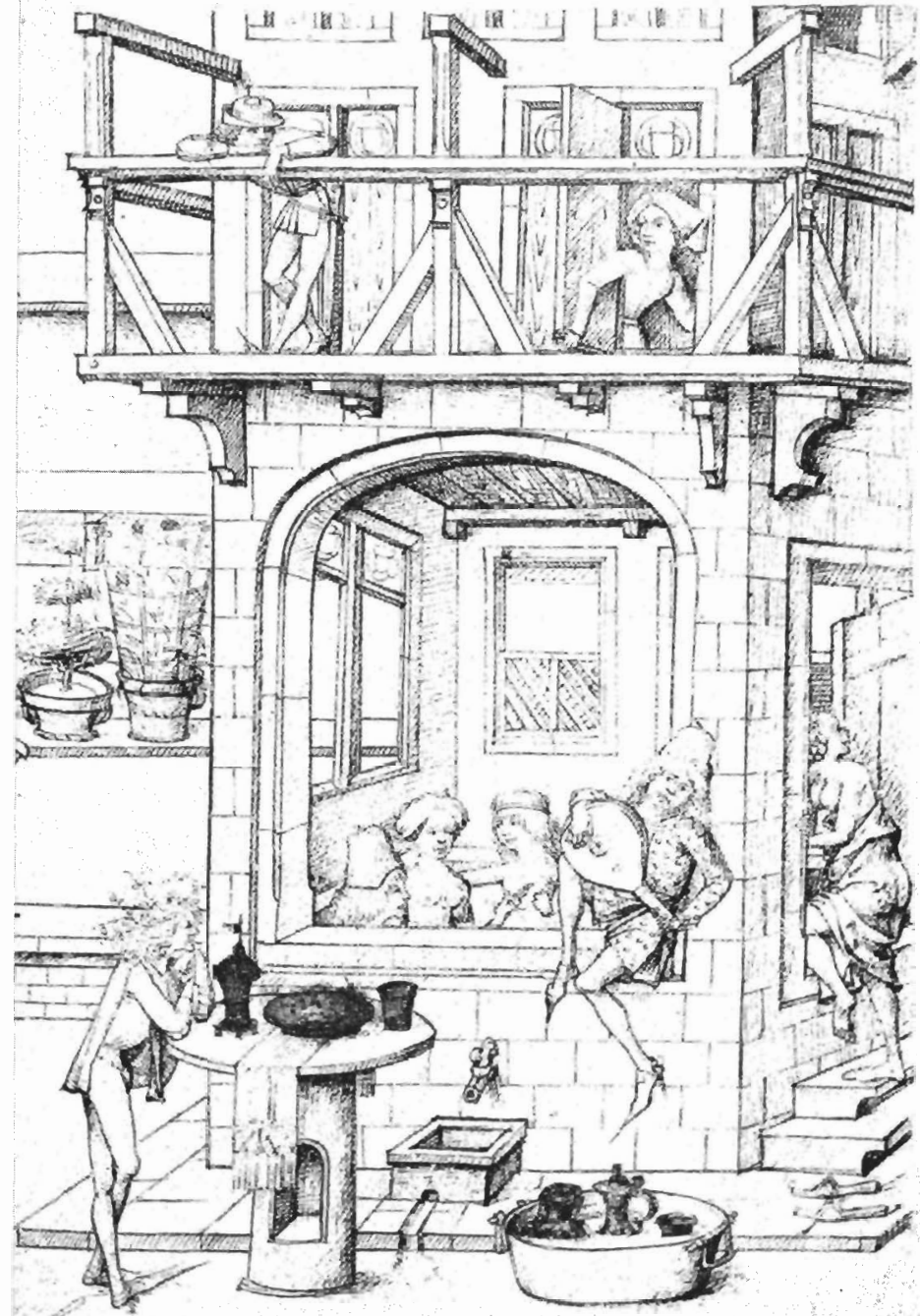

roth

ydre samfundsmæssige kontrol.

Den nøgne krop er heller ikke fremstillet på en måde, som man sidenhen har set på "privattegninger«, der gik fra hånd til hånd i 
al hemmelighed. Disse kærlighedsscener er alt andet end »obskøne«. Kærligheden er her fremstillet som ethvert andet forhold i ridderens liv, som turneringer, jagt, krigstog eller plyndring. Scenerne er ikke specielt fremhævede; i denne fremstilling mærker man intet til den voldsomhed, der klæber ved alt »obskønt«, denne tendens til at ægge, eller kompensere for noget der er blevet fornægtet i det virkelige liv. Denne fremstilling udspringer ikke fra en knuget sjæl; den afslører ikke noget »hemmeligt « eller gennembryder noget tabu. Den forekommer helt uproblematisk. Også i dette tilfælde har mesteren nok afbildet, hvad han tit selv har set i sit liv. Og p.g.a. den uproblematiske selvfølgelighed, hvor med forbindelsen mellem kønnene, sammenlignet med vor skam- og pinagtighedstærskel, bringes for en dag, kalder vi denne holdning "naiv«. Man kan endog enkelte steder finde en - efter vore begreber - ret plump spøgefuldhed hos husbogsmesteren, ganske som hos de andre mestre fra denne periode, f.eks. hos mester E.S, og, måske kopieret efter denne, hos den populariserende "Meister mit den Bandrollen«. At en populariserende kopist, der muligvis endda var munk, overtager sådanne motiver, viser, hvorledes skamfølelsens samfundsmæssige standard var anderledes. Sådanne ting bliver fremført lige så selvfølgeligt som en detalje i klædedragten. Det er på samme måde grov spøgefuldhed, når man lader en skjortesnip titte frem hos den udplyndrede og forfulgte bonde, som ridderen derefter kan holde ham fast $\mathrm{i}$, eller når man lader den gamle tjenestepige, der ser de unge menneskers kærlighedsleg, lave en grimasse, som for at spotte hende fordi hun er for gammel til sådanne fornøjelser.

Det er altsammen udtryk for sjælelejet i et samfund, hvor man hengav sig lettere, hurtigere og mere spontant og åbent til drifter og følelser, hvor affekterne spillede mere ubundet end senere, hvilket også vil sige mere ureguleret og mere pendlende mellem stærke extremer. Der var dog ganske sikkert betragtelige differentieringer inden for denne affektreguleringsstandard, der var karakteristisk for hele middelalderens verdslige samfund, for bønder som for riddere. Også denne standards mennesker var pålagt en mængde driftsforsagelser. De gik blot $i$ en anden retning de havde ikke det samme omfang, som i senere perioder, og de havde 
ikke karakter af en stadig, jævn og næsten automatisk selvtvang. De integrations- og afhængighedsformer under hvilke disse mennesker levede med hinanden fordrede ikke, som tilfældet blev sidenhen, at man i den grad tilbageholdt sine kropslige funktioner eller tæmmede sin angrebslyst. Dette gjaldt alle. Men for bonden var angrebslystens spillerum mere begrænset end for ridderen, nemlig til de ligestillede. Omvendt var ridderen netop mindre begrænset, når han skulle agere uden for sit eget lag end hvis han skulle kæmpe inden for det, for her blev adfærden reguleret af den ridderlige kodeks. Bonden var endvidere i nogle tilfælde underlagt en sociogen forsagelse, fordi han ikke havde nok at spise. Og det må i hvert fald være en så betydelig driftsrestriktion, at den vil komme til udtryk i hele adfærden. Men ingen tænkte på at pålægge sig selv tvang m.h.t. at snyde næse eller spytte eller gå grådigt ombord i maden, og den samfundsmæssige situation nødvendiggjorde det heller ikke. Netop i den retning var tvangen større i det ridderlige lag. Hvor meget den middelalderlige affektbinding således end synes at være en enhed, målt med senere tiders affektudvikling, fandtes der indenfor den betragtelige forskelle i affektmodellering, forskelle der modsvarede selve lagdelingen idet verdslige samfund, for slet ikke at tale om det gejstlige; det står endnu tilbage at undersøge disse forskelle $\mathrm{i}$ detaljer. Man kan dog allerede øjne dem, når man ud fra disse billeder sammenligner de adeliges værdige og indimellem affekterede bevægelser med trællenes og bøndernes store og grove bevægelser.

De middelalderlige menneskers affektytringer er i det hele taget mere spontane og ubundne end den senere tids. Men de er på ingen måde ubundne og samfundsmæssigt umodellerede i en eller anden absolut forstand. I den henseende findes der intet nulpunkt. Det restriktionsfri menneske er et fantom. Arten, styrken og bearbejdnigen af forsagelser og tvang forandrer sig hundredfold i takt med afhængighedsformerne; dermed forandres også affektøkonomiens henholdsvise spænding og ligevægt, lige som graden og arten af den tilfredsstillelse, som den enkelte søger og finder.

Disse tegninger giver, set $\mathrm{i}$ sammenhæng, et vist indtryk af hvorledes ridderen søger og finder sin tilfredsstillelse. Allerede på 
dette tidspunkt måtte han tilbringe mere tid ved hoffet end tidligere. Men det er endnu borgen og gården, bakken og bækken, marker og landsbyer, træer og skove, der danner den selvfølgelige og ganske usentimentalt betragtede kulisse for hans tilværelse. Her har han hjemme og her er han herren. Hele hans tilværelse er $i$ alt væsentligt delt mellem krigstog, turnering, jagt og elskovsleg.

Men dette ændrer sig allerede her i det 15. årh. og endnu mere afgørende i det 16. årh. Ved de halvt bylignende fyrstehoffer danner der sig, dels af elementer fra den gamle adel og dels af nye opstigende elementer, et nyt aristokrati med et nyt livsrum, nye funktioner og en tilsvarende anderledes affektmodellering.

Folk føler selv denne forskel og bringer den til udtryk. I 1562 oversætter en mand ved navn Jean du Peyrat della Casas manérbog til fransk. Som titel skriver han over den "Galatée eller den måde og facon hvorpå en adelsmand bør føre sig $\mathrm{i}$ ethvert selskab«. Allerede i titlen kommer den stærkere tvang, der nu bliver pålagt adelsmanden, tydeligt til udtryk. Og i sin indledning fremhæver Peyrat endnu mere udtrykkeligt forskellen mellem de fordringer man stillede til en ridders liv og dem, som hoflivet nu stiller til adelsmandden:

"Min herre, hele adelsmandens dyd og perfektion består ikke blot $i$ at give en hest dygtigt med sporerne, at håndtere en lanse, at holde sig godt i sin harnisk, at forstå sig på alle våben, at kunne beherske sig mellem damer eller når der gøres kur, thi det er de funktioner man stadig tillægger adelsmanden; der findes mere: tjenesten ved kongernes og prinsernes taffel, måden at afmåle sit sprog på i respekt for personers rang og stand, øjnenes holdning, fagterne og alt til det mindste tegn eller blink med øjet.«

Her er netop det, vi har set på husbogens blade, opstillet som den hidtidige dyd og fuldkommenhed, det hidtidige liv og livsrum for adelsmanden: våbnenes og elskovens gerninger. Overfor det stilles en videre fuldkommenhed og samtidig adelsmandens nye livsrum i fyrstens tjeneste.

Der pålægges nu aldesmanden en ny tvangsmæssighed, en ny og mere indgående regulering og modellering af adfærden, som det gamle ridderliv hverken havde nødigt eller gjorde muligt. Det er konsekvenserne af den nye og stærkere afhængighed, som adelsmanden nu placeres i. Han er ikke mere den relativt frie 
mand, der er herre i sin egen borg, der udgør hans hjem. Nu lever han ved hoffet. Han tjener fyrsten. Han gør ham sin opvartning ved taflet. Og ved hoffet lever han sammen med mange mennesker. Han må lære at afmåle sin sprogbrug nøjagtigt og endog at kontrollere sit blik. Det er en ny selvdisciplinering, en langt stærkere tilbageholdenhed, der bliver påtvunget mennesker gennem dette nye livsrum og den nye integrationsform.

Den attitude, der fandt sit ideele udtryk i begrebet "courtoisie«, går langsomt over $\mathrm{i}$ en anden, der $\mathrm{i}$ højere grad finder sit udtryk $\mathrm{i}$ begrebet »civilité«.

Jean du Peyrats oversættelse af Galateo repræsenterer også denne overgangstid hvad den sproglige form angår. Indtil 1530 eller 1535 er begrebet "courtoisie« temmeligt enerådende i Frankrig. Mod slutningen af århundredet vinder begrebet "civilité« langsomt forrang, uden at det andet dog fortaber sig. Her i 1562 bliver de begge anvendt samtidig uden nogen mærkbar rangfølge.

"Denne bog der omhandler institutionen omkring en ung hofmand og adelsmand skal være en garanti for den, der er som mønster og spejl for andre hvad angår courtoisie, civilité, gode sæder og rosværdige klæder «, siger Peyrat i sin dedikation.

Men den mand, som disse ord henvender sig til, er netop Henrik af Bourbon, prins af Narvarra, hvis livsbane i sig selv tydeligt symboliserer denne overgang fra ridder- til hofmenneske. Som Henrik IV bliver han den direkte fuldbyrder af denne forandring $i$ Frankrig, og han må, tit imod eget ønske, tvinge eller endda dræbe den genstridige, der ikke kunne begribe, at de fra at have været frie herrer og riddere skulle blive afhængige tjenere for kongen.

Oversat af Nils Gunder Hansen 